\title{
TETRACYCLINE INHIBITION OF MYCOPLASMA RIBOSOMAL PROTEIN SYNTHESIS
}

\author{
Garl G. Fraterrigo and D. Perlman \\ School of Pharmacy, University of Wisconsin, \\ Madison, Wisconsin 53706 U.S.A.
}

(Received for publication January 5, 1971)

\begin{abstract}
Polyuridylic acid directed protein synthesis by ribosomes from tetracyclinesensitive and tetracycline-resistant cells of Mycoplasma laidlawii B was found to be sensitive to tetracycline. The ribosomal preparations were somewhat more sensitive to tetracycline than mixtures of ribosomes and cell membrane fragments. No requirement for an exogenous $m$-RNA could be demonstrated with the latter preparations.
\end{abstract}

In the past several years, the mechanism of protein biosynthesis in plant, animal and bacterial systems has been extensively investigated and at the present time is relatively well understood ${ }^{1}$. The basic mechanisms in all these free-living forms appear to be essentially the same. In several brief reports $\left.{ }^{2 \sim 4}\right)$ TourtellotTe et al. described cell-free protein synthesis in Mycoplasma laidlawii B in which similarities with other organisms were noted. They utilized a mixture of ribosomes and cell membranes in these studies, and the contributions of each of these components to the protein synthesis was not clearly defined. We have been successful in obtaining ribosomal fractions from Mycoplasma cells and have used them in studying the sensitivity of protein synthesis in this system tetracycline.

\section{Materials and Methods}

\section{Materials}

The following chemicals, biochemicals and their sources were used in these studies: L-Phenylalanine-U- ${ }^{14} \mathrm{C}, \quad 374 \mathrm{mc} / \mathrm{mm}$ (New England Nuclear); adenosine triphosphate, guanosine triphosphate, phosphoenolpyruvate, pyruvate kinase, Tris buffer, and polyuridylic acid (all from Sigma Chemical Company); soluble ribonucleic acid (as sodium salt) (General Biochemicals Inc.); dithiothreitol and $\beta$-mercaptoethanol (Calbiochemicals); Lamino acids (Mann Research Laboratories); tetracycline hydrochloride (Lederle Laboratories).

\section{Cultures}

A culture of Mycoplasma laidlawii B was obtained from Prof. H. E. Morton (University of Pennsylvania) and was maintained on PPLO agar supplemented with PPLO serum fraction (Difco). A mutant of this culture resistant to $50 \mu \mathrm{g} / \mathrm{ml}$ tetracycline was obtained by repeated exposure of the parent (which is sensitive to $2 \mu \mathrm{g} / \mathrm{ml}$ tetracycline). This mutant has maintained its resistance when transferred on media containing tetracycline.

Methods

Preparation of Mycoplasma laidlawii cells: Four 2-liter cotton-plugged flasks each containing 1-liter quantities of sterile tryptose broth (Tryptose (Difco), $20 \mathrm{~g} ; \mathrm{NaCl}, 5 \mathrm{~g}$; Tris buffer, $3.7 \mathrm{~g}$; glucose, $10 \mathrm{~g}$; distilled water, q. s. 1 liter; $\mathrm{pH}$ adjusted with $\mathrm{NaOH}$ to $\mathrm{pH} 8.0 \sim 8.2$ before autoclaving for 30 minutes at $121^{\circ} \mathrm{C}$ ) were supplemented with $5 \mathrm{ml}$ of 
PPLO serum fraction (Difco) and inoculated with $50 \mathrm{ml}$ of a 24-hour old culture of $M$. laidlawii $\mathrm{B}$ grown in the same medium. The flasks were incubated for 12 hours at $37^{\circ} \mathrm{C}$ (without shaking) and the cells collected by centrifugation at $5,000 \mathrm{rpm}(3,000 \times g)$ for 15 minutes at $4^{\circ} \mathrm{C}$. The $1 \mathrm{~g}$ of collected cells was washed with $10 \mathrm{ml}$ of chilled medium and centrifuged at $5,000 \times g$ for 20 minutes at $4^{\circ} \mathrm{C}$.

Preparation of ribosomes + cell membrane fragments: One gram of cells was suspended in $7 \mathrm{ml}$ of $0.01 \mathrm{M} \mathrm{pH} 7.8$ Tris buffer containing $\mathrm{Mg}\left(\mathrm{C}_{2} \mathrm{H}_{3} \mathrm{O}_{2}\right)_{2}$ (final concentration $0.01 \mathrm{M}$ ), $\mathrm{KCl}$ (final concentration $0.06 \mathrm{M}$ ), $\beta$-mercaptoethanol (final concentration $0.006 \mathrm{M}$ ) and crushed twice in a Aminco French press $(4,000 \mathrm{lbs} / \mathrm{sq}$. in.). The resulting paste was then homogenized in a glass Potter-Elvehjen homogenizer. The resulting slurry was utilized immediately without storage.

Preparation of ribosomes: Ribosome preparations free of membrane were obtained by taking $1 \mathrm{~g}$ of cell paste (obtained by the centrifuging mentioned above) suspended in $4 \mathrm{ml}$ of $0.01 \mathrm{M}$ pH 7.6 Tris buffer containing $\mathrm{Mg}\left(\mathrm{C}_{2} \mathrm{H}_{3} \mathrm{O}_{2}\right)_{2}$ (final concentration $0.016 \mathrm{M}$ ), $\mathrm{KCl}$ (final concentration $0.06 \mathrm{M}$ ), and dithiothreitol (final concentration, $0.1 \mathrm{~mm}$ ). This suspension was placed in a $5 \mathrm{ml}$ cup containing $3 \mathrm{ml}$ of $120 \mu$ glass beads attached to a Vibrogen cell mill (Model 600-00, manufactured by the Edmund Buhler Co.). The mill was operated at maximum speed for 30 minutes and the cup was maintained at $0^{\circ} \mathrm{C}$ by continuously passing chilled ethylene glycol through the jacket. The broken cell-bead mixture was then centrifuged at $18,000 \times g$ for 30 minutes at $4^{\circ} \mathrm{C}$ and the supernatant solution dialyzed at $4^{\circ} \mathrm{C}$ overnight against the Tris buffer- $\mathrm{Mg}\left(\mathrm{C}_{2} \mathrm{H}_{3} \mathrm{O}_{2}\right)_{2}-\mathrm{KCl}$-dithiothreitol solution. This dialyzed $\mathrm{S}-30$ fraction was stored in small quantities at $-20^{\circ} \mathrm{C}$ and activity was maintained for at least 10 days under these storage conditions.

Determination of protein synthesizing ability: The reaction mixture for the crushed cells -- membranes contained: Tris buffer, $\mathrm{pH} 7.8,100 \mu \mathrm{M} ; \mathrm{KCl}, 50 \mu \mathrm{M} ; \mathrm{Mg}\left(\mathrm{C}_{2} \mathrm{H}_{3} \mathrm{O}_{2}\right)_{2}$, $10 \mu \mathrm{M} ; \beta$-mercaptoethanol, $6 \mu \mathrm{M}$; adenosine triphosphate, $1 \mu \mathrm{M}$; phosphoenolpyruvate, 5 $\mu \mathrm{M}$; phosphoenolpyruvate kinase, $2 \mu \mathrm{g}$; the 20 amino acids commonly found in proteins (except for phenylalanine), $0.05 \mu \mathrm{M} ;$ L-phenylalanine-U- ${ }^{14} \mathrm{C}$ (sp. act. $187 \mu \mathrm{Ci} / \mu \mathrm{M}$ ) $0.1 \mu \mathrm{Ci}$; L-phenylalanine, $26 \mu \mathrm{M}$; crushed cells (including membranes) $50 \mu \mathrm{g}$ protein ; total volume, $0.10 \mathrm{ml}$.

The reaction mixture for the ribosomes contained: Tris buffer, $\mathrm{pH} 7.6,50 \mu \mathrm{M}$; $\mathrm{Mg}\left(\mathrm{C}_{2} \mathrm{H}_{3} \mathrm{O}_{2}\right)_{2}, 18 \mu \mathrm{M} ; \mathrm{NH}_{4} \mathrm{Cl}, 50 \mu \mathrm{M}$; dithiothreitol, $0.1 \mu \mathrm{M}$; adenosine triphosphate, $1 \mu \mathrm{M}$; guanosine triphosphate, $0.5 \mu \mathrm{M}$; phosphoenolpyruvate, $5 \mu \mathrm{M}$; phosphoenolpyruvate kinase, $2 \mu \mathrm{g}$; polyuridylic acid, $10 \mu \mathrm{g} ; t$-ribonucleic acid (from Escherichia coli B), $0.1 \mathrm{mg} ; \mathrm{L}-$ phenylalanine-U- ${ }^{14} \mathrm{C}$ (specific activity $187 \mu \mathrm{Ci} / \mu \mathrm{M}$ ), $0.1 \mu \mathrm{Ci} ; \mathrm{L}$-phenylalanine, $26 \mu \mathrm{M}$; total volume, $0.10 \mathrm{ml}$. In those reactions in which the $\mathrm{S}-30$ fraction was used, there was approximately $0.1 \mathrm{mg}$ protein added to the reaction mixture. In the other experiments where the ribosomes were separated from the supernatant solution, $0.09 \mathrm{mg}$ ribosomes and $0.09 \mathrm{mg}$ of supernatant protein were added to the reaction mixture.

The reaction mixtures were incubated for up to 60 minutes at $37^{\circ} \mathrm{C}$ and then chilled in ice water. One $\mathrm{ml}$ of distilled water and $0.05 \mathrm{ml}$ of $10 \%$ bovine serum albumin were added followed by $1.0 \mathrm{ml}$ of $10 \%$ trichloroacetic acid. The resulting suspension was heated at $100^{\circ} \mathrm{C}$ for 15 minutes, chilled, and the precipitate collected on a Millipore filter. The collected precipitate was washed with $5 \%$ trichloroacetic acid, the filters dried and the absorbed radioactivity determined in a Packard TriCarb liquid scintillation spectrometer (model 2002) using BRAY's solution ${ }^{5)}$.

Protein determination: The biuret method was used with crystalline bovine serum albumin as standard ${ }^{6}$.

\section{Results}

Experiments with Crushed Cells :

The incubation was performed as described above. The optimum conditions for 
protein synthesis was found to be: 30 minutes incubation time; $37^{\circ} \mathrm{C}$ incubation temperature; about $10 \mu \mathrm{M}$ $\mathrm{Mg}\left(\mathrm{C}_{2} \mathrm{H}_{3} \mathrm{O}_{2}\right)_{2}$ per $0.1 \mathrm{ml}$ reaction mixture; $\mathrm{pH}$ 7.8. No difference in protein synthesis was noted when polyuridylic acid was added to the mixture. The inhibition of protein synthesis noted when tetracycline
Table 1. Tetracycline inhibition of protein synthesis by crushed cells of Mycoplasma laidlawii B

\begin{tabular}{|c|c|c|}
\hline \multirow{2}{*}{$\begin{array}{l}\text { Amount tetracycline } \\
\text { present in } \\
\text { reaction mixture }\end{array}$} & \multicolumn{2}{|c|}{$\begin{array}{l}\text { Counts } / \mathrm{min} \text {. of protein by } \\
\text { crushed cell preparations from: }\end{array}$} \\
\hline & $\begin{array}{l}\text { Tetracycline- } \\
\text { sensitive cells }\end{array}$ & $\begin{array}{l}\text { Tetracycline- } \\
\text { resistant cells }\end{array}$ \\
\hline None & 1293 & 949 \\
\hline $6.2 \times 15^{-5} \mathrm{M}$ & 249 & 326 \\
\hline $6.2 \times 15^{-6} \mathrm{M}$ & 937 & 814 \\
\hline $6.2 \times 15^{-7} \mathrm{M}$ & 1240 & 889 \\
\hline
\end{tabular}
was added to the reaction mixture containing crushed cell fragments and ribosomes. from both the tetracycline-sensitive $M$. laidlawii B and a tetracycline-resistant mutant is summarized in Table 1. Addition of tetracycline to give a final concentration of about $6 \times 10^{-5} \mathrm{M}$ decreased protein synthesis by more than $50 \%$ with both crushed cell preparations.

\section{Experiments with Ribosomes}

The procedure mentioned above was used with the ribosomes. A definite requirement was found for polyuridylic acid for protein synthesis by ribosomes from the tetracycline-sensitive and from the tetracycline-resistant $M$. laidlawii, and protein synthesis was inhibited by addition of tetracycline. Some of the data collected in this. study are summarized in Table 2.

Table 2. Tetracycline inhibition of protein synthesis by ribosomes from Mycoplasma laidlawii B

\begin{tabular}{c|c|c|c|c}
\hline \multirow{2}{*}{$\begin{array}{c}\text { Amount tetracycline } \\
\text { present in } \\
\text { reaction mixture }\end{array}$} & \multicolumn{3}{|c}{ Counts/min. of protein formed by ribosomes from: } \\
\cline { 2 - 5 } & $\begin{array}{c}\text { Tetracycline-sensitive cells } \\
\text { System+ } \\
\text { polyuridylate }\end{array}$ & $\begin{array}{c}\text { System without } \\
\text { polyuridylate }\end{array}$ & $\begin{array}{c}\text { System+ } \\
\text { polyuridylate }\end{array}$ & $\begin{array}{c}\text { System without } \\
\text { polyuridylate }\end{array}$ \\
\hline None & 2205 & 506 & 1965 & 935 \\
$6.2 \times 10^{-5} \mathrm{M}$ & 601 & & 955 & 1683 \\
$6.2 \times 10^{-6} \mathrm{M}$ & 1136 & & 1854 & \\
$6.2 \times 10^{-7} \mathrm{M}$ & 2041 & & & \\
\hline
\end{tabular}

\section{Discussion}

Requirements for protein synthesis by $M$. laidlawii ribosomes :

Definite requirements for the $105,000 \times g$ supernatant solution, ribosomes, adenosine triphosphate, phosphoenolpyruvate, phosphoenolpyruvate kinase, guanosine triphosphate, $\mathrm{Mg}\left(\mathrm{C}_{2} \mathrm{H}_{3} \mathrm{O}_{2}\right)_{2}$ (more than $13 \mu \mathrm{M}$ per $0.1 \mathrm{ml}$ reaction mixture), and dialysis of the ribosomal fraction were demonstrated by elimination experiments. No requirement for cytosine: triphosphate, uridine triphosphate, and the 20 common amino acids found in proteins. (except for phenylalanine) could be demonstrated in these elimination experiments. In similar studies with the crushed cells no requirements for $t$-ribonucleic acid, polyuridylic: acid, guanosine triphosphate, and $\mathrm{Mg}\left(\mathrm{C}_{2} \mathrm{H}_{3} \mathrm{O}_{2}\right)_{2}$ could be demonstrated.

Differences with previously reported studies:

The earlier studies by Tourtellotte et al. ${ }^{2 \sim 4)}$ showed that protein synthesis by crushed. cell preparations (including membranes) required particulate materials from the cells. Endogenous incorporation of amino acids into protein occurred. It seems likely that the ribosomes were intimately involved with the cell membranes and for some reason poly- 
uridylic acid could not bind to them. The Vibrogen cell mill prepared S-30 fractions of Mycoplasma are more active than the crushed cell preparations because no cell membranes are needed for high incorporations of phenylalanine into trichloroacetic acid precipitatable protein.

Origin of tetracycline resistance in Mycoplasma:

It appears from the data summarized in Tables 1 and 2 that tetracycline resistance in Mycoplasma is due to some transport phenomenon with the cell membrane being the mediator of this process. If a ribosomal mechnism is involved we expect that the cell-free systems from the tetracycline-resistant mutant would be less sensitive to tetracycline than those from the tetracycline-sensitive parent culture.

\section{Acknowledgements}

This investigation was supported by the Graduate School Research Fund, University of Wisconsin, and by Public Health Service Research Grant AI-09320-01 from the National Institute of Allergy and Infectious Diseases. We are indebted to Professor B. Wersblum for advice and criticism.

\section{References}

1) Lengyed, P. \& D. SöLl: Mechanism of protein biosynthesis. Bact. Rev. 33:264 301, 1969

2) Tourtellotte, M. E. \& H. J. Morowitz: Cell-free protein synthesis in Mycoplasma laidlawii. Bacteriol. Proc. p. 112, 1963

3) Tourtellotte, M. E.; M. E. Pollack \& R. P. Malewaik: Protein synthesis in Mycoplasma. Ann. N. Y. Acad. Sci. $143: 130 \sim 138,1967$

4) Tourtellotte, M. E.: Protein synthesis in Mycoplasmas. in The Mycoplasmatales and the L-Phase of Bacteria (Leonard HAYflick, editor). pp. 451 468. New York: Appleton-CenturyCrofts, 1969

5) Bray, G. A.: A simple efficient liquid scintillator for counting aqueous solutions in a liquid scintillation counter. Anal. Biochem. 1:279 285, 1960

6) LAYNE, E.: Spectrophotometric and turbidimetric methods for measuring proteins. in Methods in Enzymology. Volume III (S. P. Colowick \& N. O. KAPLAN, editors). pp. 450 451. New York: Academic Press, Inc. 1957 